\title{
Teachers' use of a school library in a South African township school: closing the literacy gap
}

\author{
Nicoline Wessels' and Nampombe Mnkeni-Saurombe ${ }^{2}$ \\ Department of Information Science, University of South Africa \\ wessen@unisa.ac.za; mnkennp@unisa.ac.za
}

\begin{abstract}
Received 22 February 2012
Accepted 25 May 2012

This post-project study investigates the use of the school library at a primary school by teachers at the end of a literacy project, without the guidance of the project facilitators at the school. The article gives background information about the Academic Literacy Research Project Unit (ALRU) from the University of South Africa which established a school library at school $P$ as part of the literacy research project. The aim of the Literacy Project was to improve literacy levels and create a strong reading culture that would later have a positive impact on the academic progress of learners at school $P$. The Literacy Project involved training teachers in literacy and reading matters. In addition to the teacher training, a school librarian was trained to manage the school library. At the onset of the post-project study, self-administered questionnaires were drawn up to collect data on the teachers' school library practices after withdrawal of the project team. The questionnaires included qualitative and quantitative questions. The findings suggest that the school library is being utilised and appreciated as an integral part of the learning process; however, the teachers seem to need further exposure and training on information literacy. The authors hope that the information and interpretations provided in this article will be helpful in achieving the goal of quality education in South Africa and especially in improving the reading and literacy levels of all learners.
\end{abstract}

Keywords: School library, teachers, learners, literacy, primary school education, South Africa, reading; information literacy

\section{Background}

The Academic Literacy Research Unit (ALRU) at UNISA conducted a literacy research project in an urban township primary school called School P from 2006 to 2009. (We use a pseudonym for the purpose of anonymity). As part of the project a school library was set up in a classroom cum office area which was originally earmarked to be a computer centre. After four years of involvement at the school the Literacy Project ended. It left not only a legacy of literacy knowledge, but also a tangible legacy in the form of an established and functional school library with a collection of over 5000 books, a computerised library system and an informally trained, capable and enthusiastic part time school librarian.

To ground the current post-project study, we briefly provide the context School $\mathrm{P}$ operates from and explain its participation in the Literacy Project. School P has 16 teachers and 600 learners. It is an underprivileged school situated in a middle class neighbourhood in one of Pretoria's oldest townships. However, the school's learners come mostly from informal settlements and poor families in the area and the school is under-resourced. The single storeyed school building is 39 years old, has 15 classrooms and an office area, but no school hall. The classrooms have cement floors (many need to be repaired) and few cupboards. The school is fenced and gated and the school grounds are reasonably neat, but there are no sports fields.

The school asked to become part of the Literacy Project with the internal aim of the principal, teachers and the school management to develop a reading culture. The literacy transformation of the school society (teachers, learners and parents) has been slow, but there was an impact regardless of various problems and obstacles (Currin \& Pretorius 2010; Wessels 2010). The influence of the Literacy Project is evident in print rich walls and book corners in some classrooms and in the above-mentioned library. With the permission of School P, ALRU decided to continue with a post-project observation phase with specific emphasis on the use of the school library by teachers and learners. This article focuses specifically on teachers and their utilisation of the school library after the conclusion of the Literacy Project and endeavours to analyse and explain the findings.

\section{Literacy, teachers and school libraries in South Africa}

Much has been written about the education system and teachers in South Africa. The transformation of education has come about slowly since 1994 and the explanations for this are manifold. Reasons such as poverty, political will, old apartheid inequalities, too many curriculum changes, poor administration and school leadership are mentioned (e.g. NEEDU 2009; SAHRC 2006). Furthermore, various official government reports have explicitly shown that many teachers

I. Nicoline Wessels is a lecturer in the Department of Information Science at the University of South Africa

2. Nampombe Mnkeni-Saurombe is a lecturer in the Department of Information Science at the University of South Africa 
are a deterrent to quality education in South Africa (NEEDU 2009; SAHRC 2006; South Africa. Department of Education 2005). NEEDU (2009:26) indicates that "the support given to struggling teachers is rarely translated into practice because of their poor attitudes, culture and commitment to improve".

South African learners score low in national and international reading tests (Mothibeli 2005; PIRLS 2006 2007; South Africa. Department of Education. 2005; South Africa. Gauteng Department of Education 20I0.) It is a well-publicised fact that South-African learners fared very badly in the 2006 Progress in International Reading Literacy Study (PIRLS) evaluation and came last out of forty countries tested (PIRLS 2006 2007:38). In comparison, Finland has scored consistently high in reading tests in the developed world. This could be attributed to the fact that in Finland teachers are highly regarded. On the one hand teaching is seen as a prestigious career and on the other hand expectations of these teachers are high. In Finland a Masters degree is a prerequisite to a teaching career (Burridge 2010). Finnish teachers also regard a reading culture as essential to a successful education.

Currently there are around 28000 public primary and high schools in South Africa. The latest figures show that only $7.23 \%$ of these schools have functional school libraries (Equal Education 2010:1; Rademeyer 2010:15). National and international research have shown that school libraries can be important tools in teaching regardless of the educational paradigm (e.g. Equal Education 2010:II; Wessels 2010:29). Bloch \& Ndebele (2010) point out that [functional] school libraries can play a role in improving learners' reading skills and academic performance by between 10 and 20 percent. With the partial demise of the OBE curriculum and the introduction of its replacement Schooling 2025 (Jones 2010:4) teachers and learners will need libraries and information perhaps less for the completion of portfolio tasks, but more for knowledge creation and improvement of reading and literacy skills. Schooling 2025 puts emphasis on reading and writing and as the literature has long indicated, school libraries are essential to improve these skills whether for learning purposes or for pleasure reading (e.g. Krashen 1995; Mckenzie 2010).

Working from the premise that school libraries are important in acquiring good literacy skills and in supporting teaching and learning, the question arises if South African teachers regard school libraries in the same light and if they perceive school libraries as worthwhile. Considering the background of education, teacher training and library provision under the apartheid regime, it comes as no surprise that many teachers are not readers or library users themselves and even worse, do not see the need for school libraries (Hart [nd]; Hart \& Zinn 2007:10I; Wessels 2010). That is an indication that these teachers are not equipped to understand how the library can support their teaching and the learners' learning.

\section{Meetings and workshops with teachers during the Literacy Project}

In order to understand from which base this post-project phase works, we will briefly explain what training teachers received during the Literacy Project. One of the aims of the Literacy Project was to build teacher capacity including knowledge about reading, literacy and school libraries. Regular interactions were scheduled and appropriate activities arranged.

A series of after school meetings and workshops for teachers were organised to provide a reading and literacy framework. The goal of these meetings and workshops was to work together to investigate issues, sometimes in an investigative mode and at other times teachers received direct instruction from presenters to solve problems. Learning opportunities for teachers ranged from theoretical activities such as listening to a lecture on storytelling or the weeding of books, to practical activities such as actually reading a story to the other teachers in a role play session and working together in the library weeding books. All participants were issued with project files to store workshop handouts and notes for reference purposes. The workshops familiarised teachers with a multitude of related topics such as:

- reading and literacy factors that impact on teaching approaches

- emergent literacy

- decoding and comprehension

- reading attitudes

- how to use storybook reading in the classroom to facilitate reading

- objectives of family literacy events

The workshops can be divided into four broad categories:

- self-development, for example time management

- teaching development such as the use of regular assessment tests, creating teaching materials, developing storybook reading skills

- literacy issues such as what is reading, developing reading speed, phonics, reading schema 
- school library issues

Workshops that specifically targeted library issues covered basic library practices and information literacy and how to incorporate the library and library resources into literacy practices at the school. Most teachers in the school were clearly not familiar with libraries or had very superficial knowledge of how to use a library. We had to go back and discuss the basics several times: how a school library works, the distinction between fiction, non-fiction and reference works and how the Dewey Decimal Classification system is used to organise collections and information, call numbers and subjects. We had to explain that books have authors and titles, the basic parts of a book, i.e. title page and verso, publisher and publication date, contents page, index and the role of illustrations. We had practical sessions in the school libraries on these themes as well as the use of storybooks and non-fiction to broaden both teacher and learner insights. We also gave workshops on how the school library can be integrated with curriculum outcomes. The interrelated information literacy skills of location, selection, organisation, presentation and evaluation of information were not easily understood by the teachers and most of them were not able to transfer these skills to the learners.

Regardless of the problems experienced, the teachers were well informed and were provided with a variety of learning opportunities regarding literacy issues and school libraries.

\section{The research problem of the post-project phase}

The Literacy Project attempted to put in a sustainable element by helping the teachers to work as a team and to make certain that they were committed towards literacy improvements. The idea was for the teachers to take ownership of the knowledge gained during the Literacy Project's life cycle and build onto that. However, the question remained if the teachers continue to close the literacy gap through the use of the school library without the presence of the Literacy Project members.

The research problem revolves around the question whether the school library still contributes positively to teaching and learning outcomes. Sub-questions that guide the study are:

- What has happened since monitoring of the project ended?

- Is the school library still functional?

- Who uses the school library?

- Is the school library being managed properly, and who manages the school library?

- Do the teachers use the school library for teaching?

- Do the teachers encourage learners to use the school library?

\section{Research methodology}

At the onset of the post-project study, self-administered questionnaires were drawn up to collect data on the teachers' school library practices after withdrawal of the project team. The questionnaires included qualitative and quantitative questions. Before the questionnaire was administered, it was given to an academic who teaches a module on school and youth library services to critique. The questions were then adjusted based on the academic's comments. The questionnaires were then given to the sixteen teachers who work at school $\mathrm{P}$. The respondents were given the opportunity to elaborate on their answers and to give additional comments. This article draws from data collected in the teacher questionnaire, but also from observational data from visits and qualitative data from the librarian's reports. The study is interpretive and narrative in nature. Fourteen of the sixteen (88\%) teachers completed the questionnaire.

\section{Presentation and discussion of the findings}

The research data included quantitative and qualitative data. It was interpreted and discussed on the basis of aspects that affect School $P$ teachers' literacy teaching and use of the school library. (Please note that all answers from teachers and the librarian are reproduced exactly as contained in the qualitative data from the questionnaires and librarian term reports without correction of spelling and grammatical errors.)

The data in Table I on teacher demographics is self-explanatory and provides background information on the teachers. In terms of age the largest number was in the age group 40 and older. Although not directly relevant to this study it is a concern that no young teachers participated in the Literacy Project who could continue with the knowledge and experience gained. Nine of the fourteen teachers have more than ten years' teaching experience; such individuals have used different curricula before and after 1994. Therefore, with changes that have taken place in South African primary schools, most probably these individuals can give evidence of the importance of school libraries and their contribution in establishing lifelong learners in society.

SA Jnl Libs \& Info Sci 2012, 78(I) 
Table I Respondent demographics

\begin{tabular}{llcc}
\hline Question & Response & No. & $\%$ \\
\hline Gender & Male & 4 & $29 \%$ \\
& Female & 10 & $71 \%$ \\
\hline Age groups & $20-29$ & 0 & $0 \%$ \\
& $30-39$ & 2 & $14 \%$ \\
\hline Highest Qualification & $40-49$ & 7 & $50 \%$ \\
& $50+$ & 5 & $36 \%$ \\
\hline B.Ed. Honours & B.Com. & 1 & $7 \%$ \\
& B. Arts & 1 & $7 \%$ \\
& B.Tech & 3 & $21 \%$ \\
& Advanced Certificate & 1 & $7 \%$ \\
& Diploma in Education & 1 & $7 \%$ \\
& Certificate & 3 & $21 \%$ \\
& UDEP & 2 & $14 \%$ \\
& n/a & 1 & $7 \%$ \\
\hline & $0-10$ & 1 & $7 \%$ \\
\hline
\end{tabular}

The respondents were asked to explain what they understood or knew about literacy development and school libraries after participating in workshops facilitated by the Literacy Project and using the school library.

Question: What were you taught about literacy development and school libraries during your training?

Answers included were:

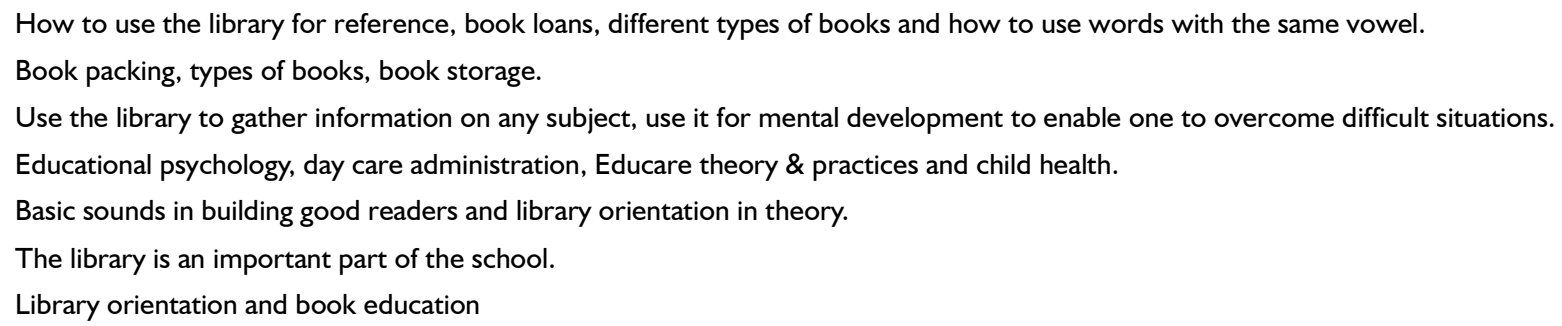

Five of the respondents indicated that they received no training on these aspects. The teachers who mentioned libraries indicated a superficial knowledge of libraries and very little about literacy development. The only library skill indicated is the use of the library for reference. No teacher referred to information literacy skills or reading for pleasure. The respondents were further questioned whether they had any further in-service training or formal/informal training regarding the use of school libraries in teaching during their teaching careers. Most of the teachers said they had no further training, except for one who mentioned training in 'Networking using ICTs'. It was not clear if this training also covered or referred to school libraries. Only four teachers listed the Literacy Project.

6.1 School library use

When the project was completed, the school library was functional with a competent school librarian managing it. The researchers wished to find out whether the teachers continue to use the library and why they did. Tables 2 and 3 show their response. 
Table 2 Frequency of school library use

\begin{tabular}{lll}
\hline Frequency & No. of Teachers & Percentage \\
\hline Daily & 2 & $14 \%$ \\
Weekly & 4 & $29 \%$ \\
Monthly & 3 & $21 \%$ \\
Occasionally & 5 & $36 \%$ \\
Rarely & 0 & 0 \\
Never & 0 & 0 \\
\hline
\end{tabular}

Table 3 Reasons for using the school library

\begin{tabular}{lll}
\hline Use & No. of Teachers & Percentage \\
\hline Lesson preparation & 7 & $50 \%$ \\
Support classroom teaching & $\mathrm{II}$ & $79 \%$ \\
Find reading materials for my learners & 10 & $71 \%$ \\
Use reference books e.g. dictionaries, encyclopaedias, etc. & 9 & $64 \%$ \\
Private study & 4 & $29 \%$ \\
Support my own reading & 1 & $7 \%$ \\
Read newspapers/magazines & 0 & 0 \\
Other & 0 & 0 \\
\hline
\end{tabular}

The results show that the teachers are reasonably active visitors to the library. However, they use the library mostly to borrow books for classroom reading or reading at assembly by learners. Their own library usage is more limited. In the second term report of 2010 the librarian wrote:

I've kept a record of educators as they visited the library without their knowledge ... I did this because of the questionnaires that [the researchers] had given the educators, hoping that together they will give a clear picture of the library usage.

This log book correlates with the data collected on library use. Some teachers accompanied learners to their reading period and to check on their book reports. One teacher brought the Grade 7 learners to do research on water pollution. One teacher borrowed a dictionary and another a world map chart. Teachers looked for information on water supply and pollution, children's rights, the importance of wood and monuments. One administrative staff member borrowed a book for leisure reading.

The respondents were further probed to point out what would make them use the library more. Table 4 shows their response.

Table 4 I would use the library more if

\begin{tabular}{lll}
\hline Reason for more school library use & No. of Teachers & Percentage \\
\hline It would support my teaching more effectively & 4 & $29 \%$ \\
More help was given & 3 & $21 \%$ \\
It was available throughout the day & 9 & $64 \%$ \\
I had more time & 7 & $50 \%$ \\
I had a specific need to do so & 1 & $7 \%$ \\
Other: The librarian was available on a daily basis. & 1 & $7 \%$ \\
\hline
\end{tabular}

It is noticeable that the comments relating to the use of the library show that teachers are not comfortable using the library independently and reveal their need for library support. 
6. 2 Marketing of the school library

Marketing school library programmes and services is an important aspect of managing the school library. This involves determining the needs of the library users, providing for these needs and telling the school library users what is available. The use of the school library can improve if the school librarian is successful at explaining the value of the school library to learners and teachers (Gordon 2005:249). When the respondents were questioned with regard to marketing of the school library, all the respondents reacted positively to this question and felt that the library was marketed adequately to the teachers. The following people and means were mentioned:

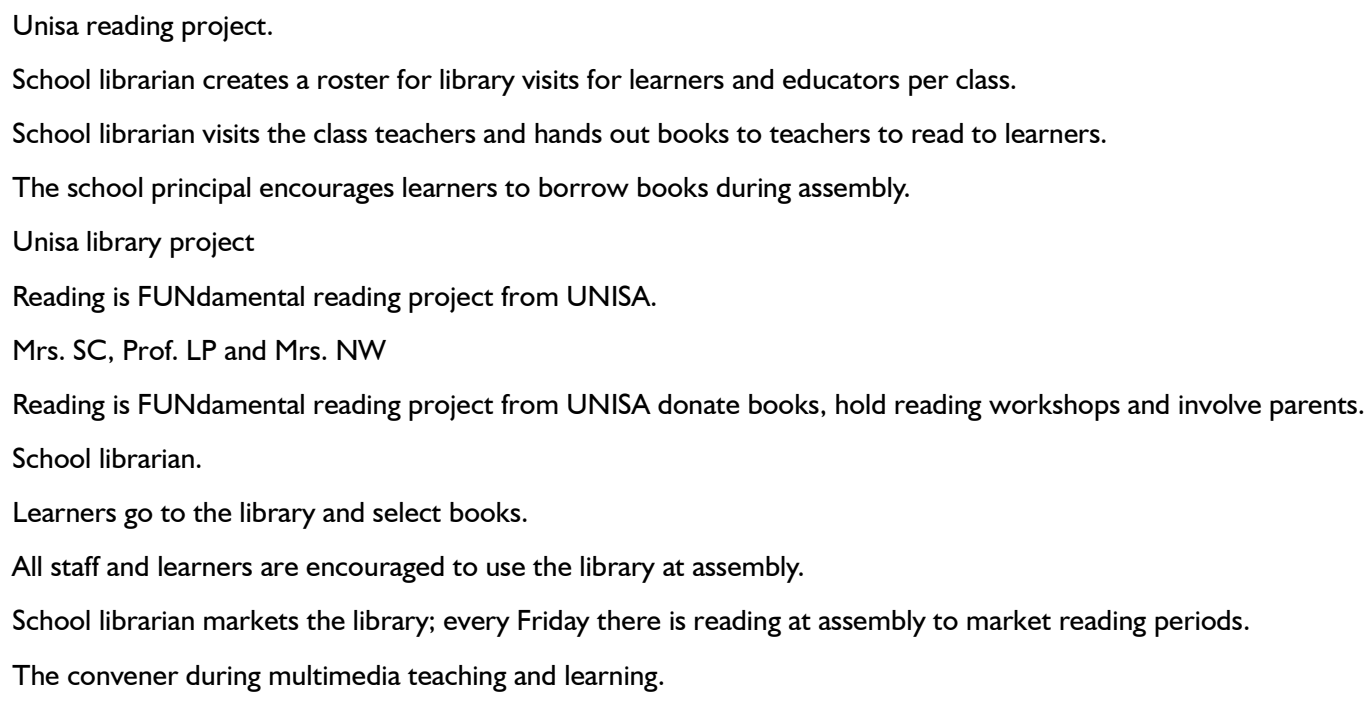

It was gratifying to see that the Literacy Project was mentioned several times and that the school librarian is pro-active. It is also encouraging that library usage is promoted to teachers and learners during school activities such as assembly.

\subsection{School library materials/resources}

One factor that ensures the success of any school library is the availability and accessibility of its resources. Moreover the quality and appropriateness of the resources are essential too. In view of this, respondents were asked a number of questions with regard to the materials in the library. The first step here was to find out whether the respondents incorporated the school library's resources in their teaching programmes.

Question: I incorporate library resources in my teaching programmes e.g. by using the resources in my lesson preparation etc. All the teachers agreed with this statement. Reasons given were:

It assists with additional resources to use in my lessons.

Learners read and I read for them. Words are explained with the help of dictionaries.

Charts, pages with relevant pictures. I ordered learners to borrow reading books in Sepedi and choose a passage for prepared reading.

Reading different stories.

Lesson plans, work schedule, learner reading - stories and other books.

Finding information for assignments and projects. Learners take books to use in class.

Photocopying materials, reading as a class and individually.

I use books that help learners to use verbs.

Allowing learners to find information for given activities.

I use library resources in lesson preparation.

I use different books on different subjects e.g. for aquamarine life learners use books on different fish species, their habitats and food. Drawings can be photocopied or traced.

I use story books for developing language lessons.

I go to the library for reference and activity work.

Finding information for the learning areas that I teach. 
This is an improvement on previous practices at the school where no additional sources were used to enhance lessons and reading stories to learners were unheard of.

Sufficiency of the resources for teaching and learning programmes was also a matter of interest. For this reason, the respondents were asked to comment on the quantity of the resources in the school library. Table 5 outlines their response.

Table 5 Quantity of school library resources

\begin{tabular}{lll}
\hline Quantity & No. of teachers & Percentage \\
\hline Too many & 3 & $21 \%$ \\
Enough & 11 & $79 \%$ \\
Too few & - & - \\
\hline
\end{tabular}

According to The Library Association there should be 13 items per learner and a minimum of 2400 resources for a school (Library Association 2000). At the time of writing this article the collection had grown to more than 5000, which means around 8.5 books per learner at school P. It is puzzling that three teachers thought there are too many books.

The questionnaire probed the respondents on the issue of the quality of the resources as well. Table 6 describes what the respondents thought about the quality of school library resources available at the school P.

Table 6 Quality of the school library resources

\begin{tabular}{|c|c|c|}
\hline Response & No. of teachers & Percentage \\
\hline Appropriate content wise & 7 & $50 \%$ \\
\hline At the right reading level for the learners & II & $79 \%$ \\
\hline Easy to use & 10 & $71 \%$ \\
\hline Too difficult for the learners & $\mathrm{I}$ & $7 \%$ \\
\hline $\begin{array}{l}\text { Other: Not so child friendly because you need to explain and help in finding information. Some of } \\
\text { the encyclopaedias are above their comprehension. }\end{array}$ & 1 & $7 \%$ \\
\hline
\end{tabular}

In this instance the majority (79\%) of the respondents were of the opinion that the materials available in the school library were appropriate for their different grades. This could be the reason the respondents easily incorporated the resources in their teaching and learning plans. The next question looked into how well these resources complemented the curriculum they followed. Table 7 shows their opinions.

Table 7 The resources in the school library

\begin{tabular}{lll}
\hline Response & No. of teachers & Percentage \\
\hline Support my teaching extremely well & 4 & $29 \%$ \\
Are adequate to support my teaching & 9 & $64 \%$ \\
Are not adequate to support my teaching & $\mathrm{I}$ & $7 \%$ \\
\hline
\end{tabular}

Nine of the respondents (64\%) claimed that the resources were adequate to support the curriculum; in addition to this the respondents were asked to provide supporting statements for their responses in Table 7. Some explanations for these answers were:

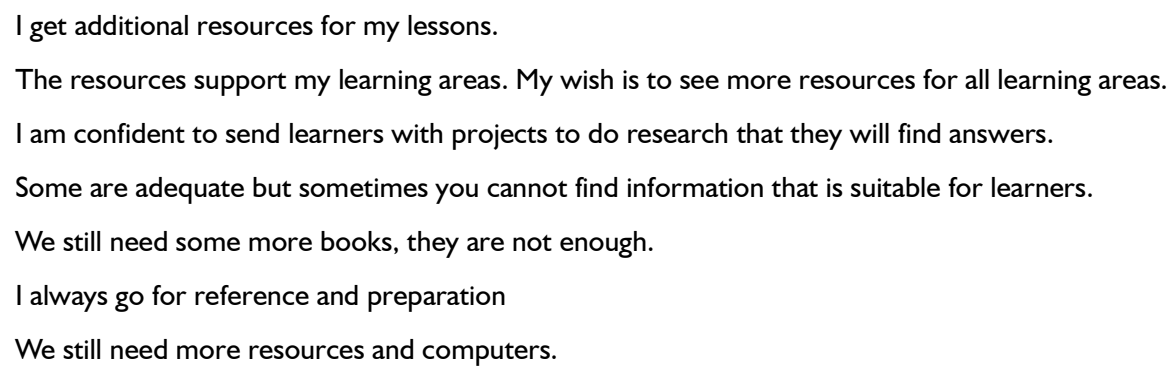


It is gratifying to notice that some teachers use the school library to design instruction as indicated above as well. The respondents were also asked what they thought was missing in their collection. Table 8 illustrates their response.

Table 8 What type of resources are lacking in your school library collection?

\begin{tabular}{lll}
\hline Resource & No. of teachers & Percentage \\
\hline Fiction & 4 & $29 \%$ \\
Non- fiction & 4 & $29 \%$ \\
Reference books & 7 & $50 \%$ \\
Fiction for teachers & 8 & $57 \%$ \\
Non-fiction for teachers & 9 & $64 \%$ \\
Magazines & 10 & $71 \%$ \\
Newspapers & 10 & $71 \%$ \\
\hline
\end{tabular}

More than $70 \%$ of the teachers felt they need magazines and newspapers, which are good sources of current affairs. Most likely these resources were required to fulfil teachers' needs. Unfortunately the question did not allow elaboration, but it brings to light the importance of the school library in addressing both teacher and learner needs.

After establishing the usefulness of the resources, the researchers wanted to establish which resources the teachers recommended to their learners and how often they did so. Their answers to these questions are demonstrated in tables 9 and 10.

Table 9 I recommend specific resources to learners

\begin{tabular}{lll}
\hline Frequency & No. of teachers & Percentage \\
\hline Frequently (more than once per term) & 7 & $50 \%$ \\
Occasionally (at least once per term) & 7 & $50 \%$ \\
Rarely & 0 & 0 \\
Never & 0 & 0 \\
\hline
\end{tabular}

Table $10 \mathrm{I}$ recommend the following to learners

\begin{tabular}{lll}
\hline Resource & No. of teachers & Percentage \\
\hline Information sources & 11 & $79 \%$ \\
Text books & 6 & $43 \%$ \\
Story books & 12 & $86 \%$ \\
\hline
\end{tabular}

The information in Tables 9 and 10 was requested to substantiate teacher responses with regard to 'school library use' in Table 2 and their reasons to do so in Table 3. The response corroborates what was said earlier.

\subsection{Organisation of resources}

The accessibility of resources in any library is reliant upon the organisation of the resources. As mentioned earlier, school $\mathrm{P}$ has a librarian who deals with the organisation of the resources. However, it was a matter of interest to establish if the respondents thought the resources were well organised to facilitate easy access. The following statement was included in the questionnaire and the respondents were asked to agree or disagree:

The resources in the library are organised and arranged in a systematic manner, making retrieval of resources easy.

All the teachers agreed with this statement. It was evident from our visits that the school librarian continued with the day to day (or in her case alternative days) housekeeping and operational routines of the library. If a collection is not organised, searching, finding and identifying sources and information becomes impossible. Information organisation is also based on the cognisance of the users of that particular collection. In this instance it would seem that the teachers are satisfied with this particular service offered by the school librarian. 
It was important to determine if the respondents physically brought their learners to the school library. Table II shows their response.

Table II I bring learners to the library

\begin{tabular}{lll}
\hline Frequency & No. of Teachers & Percentage \\
\hline Frequently (more than once per term) & 7 & $50 \%$ \\
Occasionally (at least once per term) & 4 & $29 \%$ \\
Rarely & 2 & $14 \%$ \\
Never & 1 & $7 \%$ \\
\hline
\end{tabular}

The response here indicates that there are three $(21 \%)$ teachers who rarely or never take their learners to the school library. This question provided a blank section that allowed respondents to elaborate what they recorded. The responses for those who rarely or never took learners to the library were:

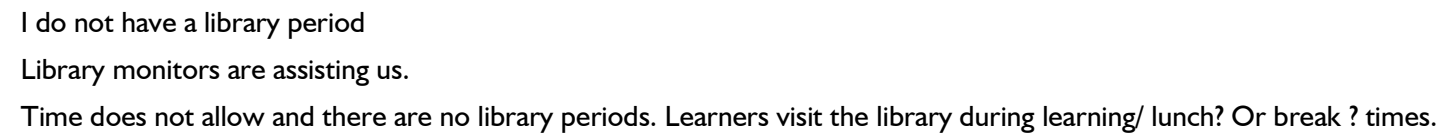

Table II also indicates that $50 \%$ of the teachers rely on the librarian to fetch and take the learners to the library and that the teachers themselves often do not participate actively. Since completion of this questionnaire library periods for all grades and classes have become a formal part of the school's time-table. In the first term report of 201 I the librarian wrote:

Our major highlights this term was having the library period being part of the school time-table ... What made me really happy was hearing from learners that library period together with reading period reflect on their time-table and that they were happy about it, that was even before the school management informed me that they've managed to squeeze in the library period on their time-table. This was welcomed by all educators as it got us out of the previous system where we relied on time for different learning areas to allow learners some time in the library.

\subsection{Information literacy}

Information literacy is a crucial element of the learners' academic development. However, this factor will not play an important role in their lives if their teachers are unaware of the concept. To determine this the following question was included in the questionnaire:

- Are you familiar with the term information literacy?

Eleven teachers indicated that they did not know what information literacy means. Three said they knew, but only one gave a satisfactory explanation.

Knowing how to get information from different resources and knowing how to use them appropriately.

Although most of the teachers have been exposed to forms of information literacy practices in the workshops they are still ignorant about this. This lack of knowledge is a worrying situation in an age where information literacy is regarded as key to becoming a successful player in the workforce and for lifelong learning. Training and development of teachers in information literacy is one of the major challenges and should be an educational priority.

6.6 School library sustainability

The Literacy Project made a big difference in school P by helping them to establish a school library and other training; however, it is the sustainability of the project that will make the necessary impact now and for generations to come. Consequently, the respondents were asked the following question:

- Do you think that the school library receives sufficient support?

Twelve teachers felt that the school library received support from school management, but two disagreed. No reasons were given for answers to this question, but in a previous question on marketing teachers indicated that the principal and 
management encouraged library use at assembly. Nine teachers said that the Department of Basic Education provided support, but five indicated that they did not agree. Reasons given were:

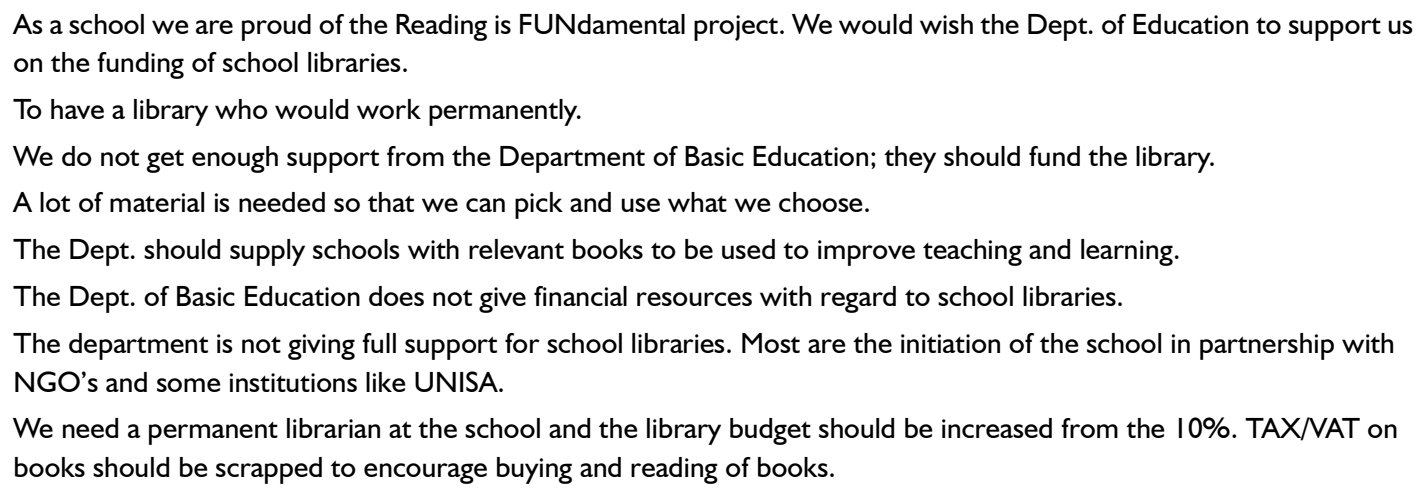

The above-mentioned reasons are a reflection of the reality. The Department of Basic Education contributed neither financial nor advisory support to the school library at School P. In fact, during the four year Literacy Project intervention no official from the Department visited the school on library issues, except by invitation on the occasion of the formal library opening. The researchers suspect that the teachers who answered in the negative are more informed about school library activities as well as those of the Department.

The improvement of current services offered at the school library is also necessary, therefore the respondents were asked:

- What additional facilities or services do you think your school library should offer to encourage more use and promote effective teaching and learning?

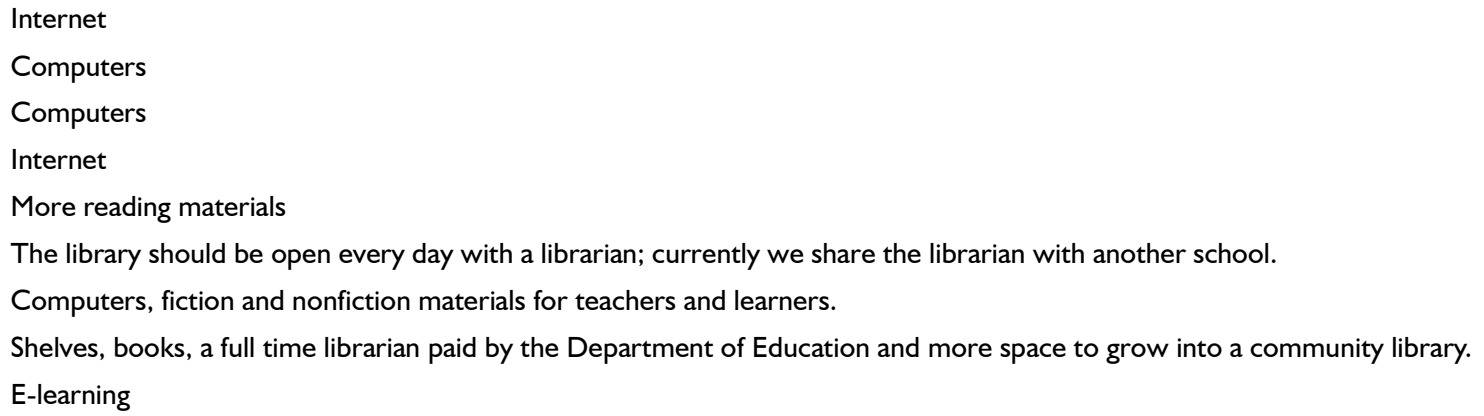

- What additional support would you like to receive in using the school library?

Additional funding from the Department to support the school library

More support materials

Access to the internet

There is enough support

More workshops

- Do you have any other comments/suggestions?

Our Dept. should be more involved in the development of school libraries.

Offer the current librarian a permanent job.

Thank you for exposing our learners to libraries at this age.

A bigger library for more books.

We are very grateful as a school for the good work done by UNISA.

More Higher Institutions to give support to school libraries.

The teachers would like to see growth and continuation of the school library. At the same time they are aware of the lack of computers and Internet access. The teachers' lack of information literacy knowledge and skills will be a challenge. McKenzie (2010) warns against the "gimmickry" of technology and stresses the importance of information literacy 
combined with "rigorous learning opportunities". Teachers need in-depth information literacy training to be able to harness the potential of the current school library and any would-be technologies. The ideal would be to have a media centre at the school, with a full-time school librarian and resources that include not only books, but also computers, multi-media and Internet access. The school librarian is rated as important and continuous investment in her is a key factor to school library success.

It is perhaps important at this stage to note that although the Literacy Project withdrew from active participation at School P, continuous financial and work related support are still provided to the school librarian. It is doubtful if the library will continue to exist if this support is withdrawn and if the Department of Basic Education continues to ignore school libraries and school librarians. From the above comments it is clear that the teachers are aware of this dilemma. Research has shown that school library success worldwide depends on good management from education departments (National Literacy Trust \& MLA 20I0).

\section{Closing thoughts}

Although this is a small scale study conducted at one school, it constitutes an in-depth study over a period of time. The authors are of the opinion that the findings are important for all disadvantaged South African schools and can be used to compare their own situations. According to Todd (2002), local evidence-based practice is essential to demonstrate the importance of school libraries.

Revisiting the research questions brings us to the positive conclusion that the school library at School P is still functional and is used by teachers and learners despite the lack of constant visits and input of the Literacy Project members. Sustaining the service continues to be a major challenge posing a threat to the continuation of this school library. It is evident that the teachers would appreciate official financial and support input from the Department of Basic Education as far as the library is concerned.

However, it is clear that the teachers are not yet confident and self-motivated users of the school library and this resource will be either under-utilised, or worse, un-utilised if they receive no motivation and support from the school librarian. Due to the effort and motivation of the school librarian (with reasonable support from the school management and library committee), the teachers use the library themselves to some extent and take the learners to the library. As a result the learners are handling and reading books and using a library, something that was not happening before the onset of the Literacy Project. There is still a long way to go and it is important that the library does not become an end in itself, but becomes more embedded in teaching and learning activities. The research could not offer real insight into the quality of the library usage, but the project has been successful in various important respects as indicated. An area that needs urgent attention is the development of information literacy skills for teachers to make their use of the library more effective and to enable them to transfer these skills to the learners.

We hope that the information and interpretations provided in this article will be helpful in achieving the goal of quality education in South Africa and especially in improving the reading and literacy levels of all learners. We believe that teachers are the key players in successful education and that their teaching and own learning can be enhanced in the following ways:

- A functional school library at each school

- An active school librarian at each school

- A sound grounding in the use of school libraries and resources

- An understanding of information literacy

The school library can be a fundamental tool in closing the literacy gap that currently exists in South Africa if the teachers use it widely and wisely. We would like to see teachers come to the understanding that school libraries can "offer equal opportunities for achievement to all students, regardless of the socio-economic or education levels of the community" (NCLIS 2008).

\section{References}

Bloch, G. \& Ndebele, N.S. 2010. The new struggle: one school, one library, one librarian. [Online]. http://writingrights.org/20I0/ 04/II/the-new-struggle-one-school-one-library-one-librarian. Accessed I4 April 2010.

Burridge, T. 2010. Why do Finland's schools get the best results? [Online]. http://news.bbc.co.uk/2/hi/programmes/ world_news_america/8601207.stm. Accessed 22 April 2010.

Currin, $\bar{S}$. \& Pretorius, L. 2010. Final report on 'Reading is Fundamental' project at Bathokwa Primary School and Patogeng Primary School, Atteridgeville for DG Murray Trust.

Equal Education. 2010. We can't afford not to: costing the provision of functional school libraries in South African public schools. Khayelitsha: Heinrich Böll Stiftung.

SA Jnl Libs \& Info Sci 20I2, 78(I) 
Gordon, R.C. 2005. The accidental library manager. New Jersey: Information Today.

Hart, G. [n.d]. School libraries in South Africa: past, present - and future? [Online]. http://www.sapartners.org/documents/ schoollibraries.pdf. Accessed II August 2006.

Hart, G. \& Zinn, S. 2007. The conundrum of school libraries in South Africa. In: Bothma, T, Underwood, P \& Ngulube P (eds). Libraries for the future: progress and development of South African libraries: World Library and Information Congress, $73^{\text {rd }}$ IFLA General Conference and Council 19- 23 August 2007 Durban. Pretoria, LIASA, pp. 89 - 107.

Jones, M. 2010. OBE 'cycle of rot' is now finally dead. Pretoria News, July 8:4.

Krashen, S.D. 1995. School libraries, public libraries and the NAEP reading scores. SLMQ, 23(4):235-237. [Online]. http:// archive.ala.or/aasl/SLMR/slmr_resources/select_krashen.html. Accessed 6 February 2008.

Library Association. 2000. The primary school library guidelines. London: Professional Practice Department of the Library Association.

McKenzie, J. 2010. Why we still need libraries and librarians. From now on: the educational technology journal 19(4). [Online]. http://fno.org/mar2010/still.html. Accessed 25 March 2010.

Ministerial Committee on a National Education Evaluation and Development Unit: Final report. 2009. Government Gazette, (32I33):4-64.

Mothibeli, A. 2005. Cross-country achievement results from the SAQMEQ II project - 2000 to 2002: a quantitative analysis of education systems in Southern and Eastern Africa. Edusource Data News, 49:1-9.

Mullis, I.V.S, Marin, M.O., Kennedy, A.M. \& Foy, P. 2007. PIRLS 2006 international report: IEA's progress in international reading literacy study in primary school in 40 countries. Chestnut Hill, MA: TIMMSS \& PIRLS.

National Literacy Trust \& MLA. 2010. School libraries: a plan for improvement. [Online]. http://www.mla.gov.uk/ /media/ Filespdf/2010/policy/SLC-Report. Accessed I4 November $201 \mathrm{I}$.

NCLIS. 2008. School libraries work! [Online]. http://listbuilder.scholastic.com/content/stores/LibraryStore/pages/images/SLW3.pdf. (Accessed I4 November 20II).

NEEDU 2009 see Ministerial Committee on a National Education Evaluation and Development Unit

PIRLS 2006 see Mullis IVS et al. 2007

Rademeyer, A. 2010. Skoolbiblioteke is 'n reg. Beeld, April 9:I5.

SAHRC 2006 see South African Human Rights Commission

South Africa. Department of Education. 2005. Grade 6 intermediate phase systemic evaluation report. Pretoria.

South Africa. Gauteng Department of Education. 2010. Introduction to the Gauteng Primary Literacy Strategy. [Online]. http:// www.cso.za.org/Mngmnt-DeptEdu-LiteracyStrategy-2010-20/4.pdf. Accessed 14 November 2011.

South African Human Rights Commission. 2006. Report of the public hearing on the right to basic education. [Online]. http:// www.sahrc.org.za/sahrc_cms/downloads/RBE report.pdf. Accessed 12 May 2008.

Todd, R.J. 2002. School librarian as teachers: learning outcomes and evidence-based practice. 68th IFLA Council and General Conference, Glasgow, August I8-24, 2002. [Online]. http://www.ifla.org/IV/ifla68/papers/084-I I 9e.pdf. Accessed I I February 2008.

Wessels, N. 2010. School libraries as a literacy intervention tool in primary schools: action research in Atteridgeville. Mlnf. Unisa. 